\title{
LEKSIKON MAKANAN TRADISIONAL SUNDA \\ DI KABUPATEN KUNINGAN \\ (Kajian Etnolinguistik)
}

\author{
Yani Nurfitri Hadiyaniyah \\ Prodi S2 Bahasa dan Budaya Sunda SPs UPI \\ e-mail : aleyn.nizar@gmail.com
}

\begin{abstract}
Abstrak
Penelitian ini bertujuan untuk mendeskripsikan bentuk lingual, penamaan, makna leksikon dan bahan dasar makanan tradisional Sunda di Kabupaten Kuningan. Metode penelitian yang digunakan adalah deskriptif. Teknik mengumpulkan data, menggunakan teknik observasi partisipan, teknik wawancara, dan teknik study bibliografi. Sumber datanya adalah pusat jajanan oleh-oleh Kuningan, sentral UKM dan masyakat Kuningan. Sedangkan, objek penelitiannya adalah makanan tradisional Sunda khas Kuningan. Dari hasil penelitian ditemukan: (1) makanan tradisional Sunda khas Kuningan yang ditemukan ada 73 nama makanan tradisional. Berdasarkan bentuk lingualnya, klasifikasi nama makanan tradisional Sunda, $22(30,1 \%)$ kata dasar, 1 (1,4\%) kata imbuhan, 8 (10,9\%) kata ulang, $37(50,7 \%)$ kata majemuk, dan $5(6,8 \%)$ kata singkatan. (2) penamaan, terdapat $1(1,4 \%)$ nama makanan yang berdasarkan peniruan bunyi, $4(5,5 \%)$ berdasarkan persamaan, $29(39,7 \%)$ berdasarkan bahan, $2(2,7 \%)$ berdasarkan tempat asalnya, $5(6,8 \%)$ berdasarkan penyebutan sifat khas, $4(5,5 \%)$ berdasarkan sebagian anggapan, dan 27 (37\%) manasuka. (3) makna leksikon, semua nama makanan tradisional Sunda merupakan kata benda. (4) nama makanan tradisional Sunda di Kabupatén Kuningan berdasarkan bahannya adalah yang berbahan dasar beras ada 5 (6,8\%), tepung beras ada $7(9,6 \%)$, beras ketan ada $10(13,7 \%)$, tepung ketan ada $12(16,4 \%)$, singkong ada $8(11 \%)$, aci ada $1(1,4 \%)$, terigu ada $3(4,1 \%)$, kacang ada $6(8,2 \%)$, ubi ada $6(8,2 \%)$, jagung ada $1(1,4 \%)$, dan bahan lainnya ada $23(32 \%)$. Saran dari penelitian ini ditujukan ke beberapa pihak, yaitu: (1) guru; (2) siswa; dan (3) masyarakat.
\end{abstract}

Kata kunci: Leksikon, Makanan Tradisional, Etnolinguistik

\section{LEXICON TRADITIONAL SUNDANESE FOOD AT KUNINGAN REGENCY (A Entholinguistic Research)}

\begin{abstract}
This study aims to describe the shape of the lingual, naming, the meanings of lexicon and the basic ingredients of traditional Sundanese food at Kuningan regency. The research method is descriptive. The techniques of collecting data used participant observation technique, interview, and bibliografi technique study. The data sources collected from Kuningan's central souvenirs shop, middle-class business (UKM), and from Kuningan native people. Meanwhile, the object of this observation is Sundanese's typical traditional foods from Kuningan. The result of researched had been found that: (1) There are 73 kinds of name of Sundanese's typical traditional foods from Kuningan. Based on the lingual shape, the classification of traditional Sundanese food names are, 22(30,1\%) basic word, 1 (1,4\%) the prefix word, $8(10,9 \%)$ repeated word, $37(50,7 \%)$ compound, and $5(6,8 \%)$ abbreviation. (2) based on Naming, there are $1(1,4 \%)$ the name of the food based on the imitation of the sound, $4(5,5 \%)$ the equations, $29(39,7 \%)$ based on materials, 2 (2,7\%) based on place of origin, $5(6,8 \%)$ based on the
\end{abstract}


mention of particularity, 4 (5,5\%) based on presumption, and 27 (37\%) based on suitably of taste. (3) The meaning of lexicon, all of traditional Sundanese foods name are noun. (4) The Sundanese traditional foods in Kuningan district based on the materials, made from rice are 5 pieces $(6,8 \%)$, made from flour are 7 pieces (9,6\%), made from glutinous rice are 10 pieces $(13,7 \%)$, made from glutinous flour are 12 pieces $(16,4 \%)$, made from cassava are 8 pieces (11\%), made from cassava flour is 1 piece $(1,4 \%)$, made from wheat flour are 3 pieces $(4,1 \%)$, made from coconut are 6 pieces (8,2\%), made from sweet potato are 6 pieces (8,2\%), made from corn is 1 piece $(1,4 \%)$ and made from the other materials about 23 pieces (32\%). The advice from this research addressed for multiple parties, such as : (1) teacher; (2) student; and (3) people.

Keywords: Lexicon, Traditional Food, Entholinguistic

\section{PENDAHULUAN}

Makanan tradisional Sunda harus dipertahankan dari gempuran fast food yang semakin merajai kuliner di Indonésia, khususnya di Jawa Barat. Fenomena ini banyak ditemui di masyarakat Indonesia, baik diperkotaan maupun di pedesaan, yang perkembangan media informasi dan gaya hidupnya lebih pesat. Hal ini semakin dikuatkan lagi dengan banyaknya makanan modern yang lebih populer dari makanan tradisional. Untuk menanggulangi hal ini, diperlukan adanya tindakan untuk melestarikan makanan asli Indonesia, khususnya makanan tradisional khas Jawa Barat.

Berbagai makanan tradisional mulai diekspos dan wajib untuk dicicipi sebagai oleh-oleh khas daerah ketika seseorang berwisata ke suatu daerah. Buku-buku yang membahas tentang tempat wisata kuliner dan berbagai macam makanan pun semakin banyak. Walaupun demikian, umumnya yang menjadi sorotan adalah dalam bidang tata boga dan wisata, sedangkan dalam bidang bahasa sampai dengan kearifan lokalnya belum dipublikasikan.

Kabupaten Kuningan, merupakan salah satu Kabupaten di Jawa Barat yang mempunyai ciri khas makanan tradisional, seperti peuyeum, golono, nasi kasreng, dll. Hal ini terlihat dari banyaknya pusat oleholeh khas Kuningan. Secara umum, menurut data Dinas Pariwisata dan Kebudayaan dalam buku Makanan dalam
Khazanah Budaya (Adimihardja, 2005), makanan tradisional khas Jawa Barat yang sudah diteliti ada 218 makanan. Tapi belum diketahui berapa banyak makanan khas Sunda Kabupaten Kuningannya. Selain itu, kurangnya pengetahuan remaja dan masyarakat jaman sekarang terhadap makanan tradisional merupakan hal yang mendasari penelitian ini. Sebab, apabila masyarakatnya tidak mengenal makanan tradisionalnya, dalam jangka waktu kedepannya makanan tradisional akan mengalami kemunduran.

\section{Leksikon}

Istilah leksikal merupakan kata sipat dari leksikon (Inggris: lexicon). Kata leksikon itu sendiri berasal dari bahasa Yunani, lexicon yang artinya 'kata' atau 'kosakata'. Kata sifatnya leksikal, yakni sesuatu yang berkaitan dengan leksikon (Sudaryat, 2009: 65-66). Leksikon yang biasa disebut kosakata dapat diartikan (a) Kekayaan kata yang dimiliki oleh suatu bahasa; (b) Semua kata yang terdapat dalam suatu bahasa; (c) Idiolek; kata-kata yang dikuasai oleh seseorang atau dialek; (d) Istilah; kata-kata yang dipakai dalam suatu bidang ilmu pengetahuan; (e) Glosarium; kamus sederhana, kamus dalam bentuk ringkas, daftar kata-kata di bidang tertentu dengan penjelasannya; (f) Komponen bahasa yang memuat semua informasi tentang makna dan pemakaiannya; (g) Kamus; daftar sejumlah kata atau frasa dari 
suatu bahasa yang disusun secara alfabetis disertai batasan dan keterangan lainnya (Adiwimarta, 1978:1; Kridalaksana, 1982:98; KBBI, 1988:510); dan (h) Enslikopedi; karya universal yang menghimpun uraian tentang berbagai cabang ilmu atau bidang ilmu tertentu dalam artikel-artikel terpisah dan tersusun menurut abjad.

Dengan demikian, leksikon atau kosakata adalah sejumlah kata dalam suatu bahasa yang digunakan secara aktif maupun pasif, baik yang masih tersebar di kalangan masyarakat maupun yang sudah dikumpulkan berupa kamus. Leksikon merupakan kumpulan leksem. Makna leksem disebut makna leksikal.

\section{Penamaan}

Penamaan dan pendefinisan adalah dua buah proses pelambangan suatu konsep untuk mengacu kepada suatu referen yang berada di luar bahasa. Dalam memberi nama suatu benda, kejadian, atau peristiwa itu, terdapat beberapa gejala timbulnya idiom. Dalam kehidupannya seringkali manusia, tentu saja termasuk kita, sukar memberi nama-nama atau label-label terhadap benda-benda atau peristiwaperistiwa yang ada disekelilingnya, karena terlalu banyaknya dan sangat beragamnya benda-benda atau peristiwa tersebut. Oleh karena itu, lahirlah nama kelompok dari benda atau hal yang berjenis-jenis itu, misalnya nama binatang, nama tumbuhtumbuhan, nama buah-buahan, atau nama makanan.

Kata atau idiom merupakan penyebutan atau penamaan sesuatu yang dialami pemakainya. Dalam memberi nama sesuatu benda, kejadian atau peristiwa, bisa diklasifikasikan seperti (1) Penamaan berdasarkan tiruan bunyi atau onnomatope, merupakan dasar primitif dalam penyebutan benda. Onomatope ialah penyebutan karena samaan bunyi yang dihasilkan oleh benda itu. Persamaan dengan bunyi yang dihasilkan oleh banda benda itu; (2) Penamaan sebagian dari seluruh anggapan, gejala ini terjadi karena kita tidak mampu menyebut barang secara keseluruhan dan terperinci tetapi hanya sifat atau ciri khusus saja; (3) Penamaan berdasarkan sifat yang menonjol, berdasarkan peristiwa semantik karena adanya transposisi makna dalam pemakaian, yakni perubahan sifat menjadi benda; (4) Penyebutan berdasarkan apelatif, yaitu penyebutan berdasarkan penemu, pabrik pembuatnya, atau nama orang dalam sejarah; (5) Penamaan berdasarkan tempat asal. Sejumlah nama benda yang dapat ditelusuri berdasarkan nama tempat asal benda tersebut. Begitupun asal nama makanan; (6) Penamaan berdasarkan bahan. Ada sejumlah benda yang diambil dari bahan pokok benda itu; dan (7) Penamaan berdasarkan kesamaan, yang muncul karena memiliki sifat yang sama.

\section{Makanan Tradisional}

Konsep makanan dan minuman pada masa kini, tidak hanya berkaitan dengan kata benda yang berfungsi mengisi dan mengenyangkan perut. Akan tetapi, pemahamannya bergeser kepada persoalan lingkungan, kesehatan, dan budaya. Di dalam konteks kesehatan, manusia dianjurkan mengkonsumsi makanan yang bergizi dan mengandung kesehatan tinggi.

Menurut orang Sunda, makanan atau kadaharan adalah suatu benda yang dapat dimakan. Dalam budaya Sunda terdapat anggapan bahwa "seseorang belum dikatakan makan jika belum makan nasi dengan lauk pauknya". Misalnya, biarpun sudah makan singkong rebus satu piring, ubi jalar rebus tiga buah, jagung rebus, dan makan roti tiga potong, bahkan makan kupat tahu dan lontong, tetap saja beranggapan dirinya belum makan karena yang dimakannya bukan nasi.

Di kalangan orang Sunda, yang dikatakan makan itu adalah "makan nasi", dengan hidangan lainnya yang berfungsi sebagai penyedap rasa nasi atau deungeun 
sangu atau réncang sangu. Jenis makanan di luar nasi, seperti singkong bakar, singkong kulub, ubi rebus, roti bakar, dan talas rebus, di dalam konteks budaya Sunda disebut ngopi atau ngaleueut, biasanya disertai dengan minum air teh atau air kopi. Jenis makanan di luar makan nasi sering disebut sebagai kadaharan cangkarang-bongkang, yaitu makanan yang dianggap sebagai penyedap saja, panyelang atau pangganjel, yakni makanan sementara untuk sekedar menghilangkan rasa lapar. Oleh karena itu, jenis makanan tersebut dianggap berupa makanan kecil untuk ruab-raéb atau ruhamrahém 'ngemil, cemilan'.

Di kalangan orang Sunda makan yang dianjurkan tiga kali sehari, berfungsi untuk menjaga metabolism tubuh agar tetap segar bugar dan memiliki tenaga yang kuat sehingga mampu melakukan berbagai aktivitas. Terdapat etika makan di kalangan orang Sunda, antara lain, berdoa sebelum makan, menggunakan tangan kanan, mengambil sajian makanan, deungeun sangu, sedikit demi sedikit, tidak boleh menyisakan makanan pada piring yang digunakannya, duduk bersila bagi laki=laki atau emok bagi perempuan, dan tidak makan sambil berbicara.

\section{METODE}

Metode penelitian yang digunakan adalah deskriptif. Teknik mengumpulkan data, menggunakan teknik observasi partisipan, teknik wawancara, dan teknik study bibliografi. Sumber datanya adalah pusat jajanan oleh-oleh Kuningan, sentral UKM dan masyakat Kuningan. Sedangkan, objek penelitiannya adalah makanan tradisional Sunda khas Kuningan.

\section{HASIL DAN PEMBAHASAN}

\section{Data Leksikon Makanan Tradisional Sunda}

Berdasarkan hasil analisis deskriptif leksikon makanan tradisional Sunda di Kabupaten Kuningan terdapat sekitar 73 jenis makanan tradisional. Jenis makanan tersebut, yakni (01) ades, (02) ampyang, (03) apem, (04) awug, (05) bakasem kadongdong, (06) béca, (07) bongko, (08) bola-bola, (09) bolu ungu, (10) bubur kemplang (11) bubur lemu, (12) buras, (13) cikak, (14) cilok, (15) cimplo, (16) cuhcur, (17) cuing, (18) dodol salak, (19) dodol peuyeum, (20) dodol boled, (21) doko-doko, (22) emping, (23) gémét, (24) gemblong, (25) gemblong kancing, (26) gemblong ungu, (27) gendar, (28) getuk, (29) golono, (30) hucap, (31) jagong marning, (32) jawadah, (33) jalabria, (34) kasréng, (35) kelepon, (36) keremes, (37) ketan uli, (38) kiripik bayem, (39) kiripik nangka, (40) kiripik gadung, (41) kiripik sampeu, (42) kiripik sukun, (43) kiripik tahu, (44) koécang, (45) kuéh satu, (46) kuéh saroja, (47) kulub hui, (48) kulub sampeu, (49) leupeut, (50) manisan cermé, (51) manisan jahé (52) manisan mangga, (53) manisan roséla, (54) manisan tomat, (55) moho, (56) noga kalapa, (57) opak bakar, (58) papais monyong, (59) peuyeum ketan, (60) pia-pia, (61) putri noong, (62) rangginang, (63) raragudig, (64) rarawuan, (65) rubi- rubi, (66) rujak kangkung, (67) sasagon,(68) sop tutut, (69) tahu lamping, (70) tahu susu, (71) tumis rebung, (72) wajit Subang, dan (73) wiwingka.

\section{Struktur Leksikon Makanan Tradisional Sunda di Kabupaten Kuningan}

Berdasarkan strukturnya ditemukan lima bentuk leksikon makanan tradisional Sunda, yakni (1) bentuk tunggal, (2) bentuk turunan, (3) bentuk ulang, (4) bentuk majemuk, dan (5) bentuk singkatan (Sudaryat dkk, 2007). Dari hasil analisis data ditemukan bahwa makanan tradisional Sunda di Kabupaten Kuningan pada umumnya berupa kata majemuk 37 $(50,7 \%)$, kata dasar $22(30,1 \%)$, kata imbuhan $1(1,4 \%)$, kata ulang $8(10,9 \%)$, dan kata singkatan $5(6,8 \%)$. 


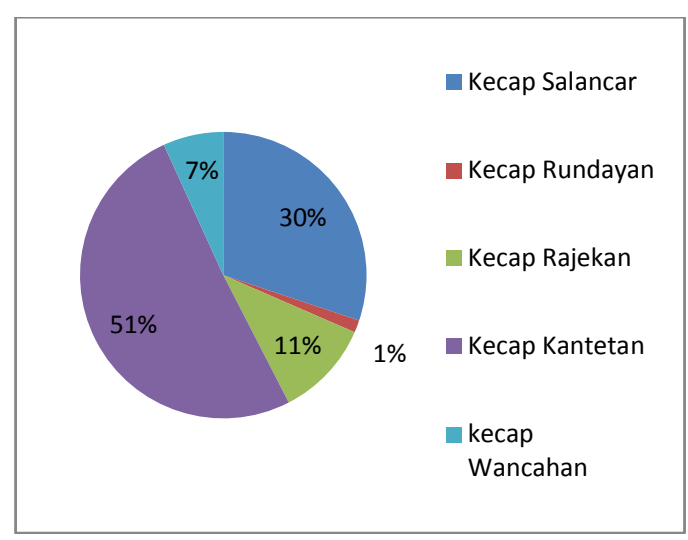

\section{Diagram 1 \\ Bentuk Lingual Leksikon Makanan Tradisional Sunda di Kabupaten Kuningan}

Pertama, leksikon bentuk tunggal merupakan leksikon yang tersusun dari satu morfem bebas. Leksikon makanan tradisional yang berbentuk tunggal ditemukan sebanyak 22 jenis. Dilihat dari jumlah suku katanya, leksikon makanan tradisinal Sunda umumnya tersusun dari

(1) Leksikon dwisuku, seperti apem, awug, béca, buras;

Berdasarkan pola sukukatanya, leksikon bentuk tunggal dwisuku terbagi kedalam sepuluh pola, yakni Pola 1 : V-KVK, pola 2: VK-KKVK, pola 3: VK-KVK, pola 4: KV-KV, pola 5: KV-VK, pola 6: KV-KVK, pola 7: KVK- KV, pola 8: KVK-KVK, pola 9: KVK-KKV, dan pola 10: KVKKKVK.

(2) Leksikon trisuku seperti golono, jawadah, kelepon, dan rangginang;

Berdasarkan pola sukukatanya, leksikon bentuk tunggal trisuku terbagi kedalam empat pola, yakni Pola 1 : $\mathrm{KV}-\mathrm{KV}-\mathrm{KV}$, pola 2: KV-KV-KVK, pola 3: KV-V-KVK dan pola 4 : KVK$\mathrm{KV}-\mathrm{KVK}$.

(3) Leksikon catursuku seperti raragudig.

Berdasarkan pola suku katanya, bentuk tunggal catursuku mempunyai satu pola, yakni Pola : KV-KV-KKV-V

Kedua, leksikon turunan berupa kata yang dibubuhi afiks. Leksikon makanan tradisional yang berbentuk kata turunan hanya ditemukan satu buah, yakni kata moho. Bentuk turunannya berupa kata berafiks $\mathrm{N}$ -

Ketiga, leksikon ulang berupa bentuk kata yang mengalami proses pengulangan, sebagian atau seutuhnya, baik disertai perubahan fonem dan pengimbuhan maupun tidak. Leksikon makanan tradisional yang berbentuk kata ulang ditemukan sebanyak delapan kata, yakni (08) bola-bola, (21) doko-doko, (60) piapia, (63) raragudig, (64) rarawuan, (65) rubi-rubi, (67) sasagon, dan (73) wiwingka. Bentuk ulangnya dapat berupa:

(1) Reduplikasi dwipurwa

(Rdp) mempunyai pola kata

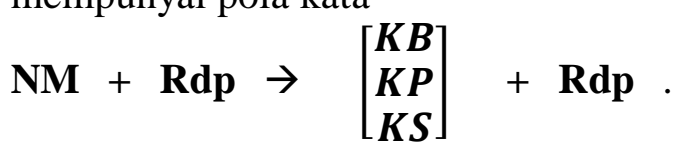

berdasarkan hasil analisis data, nama makanan yang termasuk ke dalam pola ini adalah raragudig, sasagon, wiwingka;

(2) Reduplikasi dwipurwa dengan afiksasi (Rdp+-an) mempunyai pola kata

$\mathrm{NM}+\operatorname{Rdp}-$ an $\rightarrow\left[\begin{array}{c}K B \\ K P \\ K S\end{array}\right]+\operatorname{Rdp}-\mathbf{a n}$.

Berdasarkan hasil analisi data, nama makanan yang termasuk ke dalam pola ini adalah rarawuan;

(3) Reduplikasi dwimurni (Rdm) mempunyai pola kata

$\mathrm{NM}+\operatorname{Rdm} \rightarrow\left[\begin{array}{l}K B \\ K P \\ K S\end{array}\right]+\mathrm{Rdm}$

Berdasarkan hasil analisis kata yang termasuk kedalam pola ini adalah bolabola, doko-doko, pia-pia, rubi-rubi.

Keempat, leksikon majemuk adalah bentuk kata yang merupakan hasil proses pemajemukan dengan cara menggabungkan dua kata atau lebih yang memiliki satu fokus. Leksikon makanan tradisional yang berbentuk kata majemuk ditemukan sebanyak 37 jenis. Ditemukan lima pola pemajemukan dalam makanan tradisional Sunda, yakni

(1) Pola $1: \mathrm{KB}+\mathrm{KB}$, yaitu nama makanan tradisional Sunda yang disusun oleh 
kata benda dan kata benda. Berdasarkan hasil analisis terdapat 26 makanan tradisional, seperti bakasem kadongdong, dodol salak, gemlong kancing, ketan uli, kiripik nangka, kiripik tahu, kuéh saroja, manisan cermé, tahu lamping dan wajit Subang;

(2) Pola $2: \mathrm{KB}+\mathrm{KS}$, yaitu nama makanan tradisional yang disusun oleh kata benda dan kata sifat. Berdasarkan hasil analisis terdapat empat makanan tradisional yang termasuk ke dalam pola ini, seperti bolu ungu, bubur lemu, gemblong ungu, dan papais monyong;

(3) Pola $3: \mathrm{KB}+\mathrm{KP}$, yaitu nama makanan tradisional yang disusun oleh kata benda dan kata kerja. Berdasarkan hasil analisis data terdapat tiga makanan tradisional yang termasuk ke dalam pola ini, yakni bubur kemplang, opak bakar dan putri noong;

(4) Pola 4 : KB + KBil, yaitu nama makanan tradisional yang disusun oleh kata benda dan kata bilangan. Berdasarkan hasil analisis terdapat satu nama makanan, yaitu kuéh satu; dan

(5) Pola $5: \mathrm{KP}+\mathrm{KB}$ yaitu nama makanan tradisional yang tersusun dari kata kerja dan kata benda. Berdasarkan hasil analisis data terdapat tiga nama makanan tradisional, yaitu kulub hui, kulub sampeu, dan tumis rebung.

Kelima, bentuk singkatan. Leksikon makanan tradisional Sunda di Kabupaten Kuningan bentuk singkatan yaitu makanan tradisional yang disusun dengan cara menyingkat kata. Berdasarkan hasil analisis data terdapat 5 jenis makanan tradisional, yakni (12) buras, (14) cilok, (16) cuhcur, (23) gemet, dan (30) hucap. Dalam bentuk singkatan ditemukan tiga pola singkatan, yakni

(1) Singkatan tangkesan : suku kata depan + suku kata belakang, seperti buras dan hucap. Kata 'buras' yaitu singkatan dari 'bungkus uras'. Dilihat dari bentuk singkatannya buras disingkat dengan cara menghilangkan sukukata yang berdekatan;

(2) Singkatan tingkesan : suku kata belakang + suku kata belakang, seperti cilok dan gémét. Kata 'cilok' yaitu singkatan dari 'aci dicolok', berdasarkan bentuk kata singkatannya, cilok termasuk dalam kata singkatan tingkesan, yaitu singkatan yang berupa gabungan suku kata yang diucapkan menjadi satu kata yang utuh; dan

(3) Singkatan reduksi : suku kata depan + suku kata depan, seperti cuhcur. Kata cuhcur, yaitu sinngkatan dari 'cuh curuluk'. Berdasarkan bentuknya cuhcur adalah kata singkatan reduksi, yakni singkatan yang berupa gabungan suku kata yang diucapkan menjadi kata yang memiliki makna baru.

\section{Penamaan Leksikon Makanan Tradisional Sunda di Kabupaten Kuningan}

Penamaan Leksikon Makanan Tradisional Sunda di Kabupaten Kuningan di klasifikasikan menjadi 7 kelompok.

(1) Penamaan berdasarkan peniruan bunyi, maksudanya adalah nama-nama benda atau hal yang dibentuk berdasarkan bunyi dari benda tersebut. Berdasarkan hasil analisis terdapat 1 nama makanan yang termasuk kedalam penamaan berdasarkan peniruan bunyi, yaitu keremes;

(2) Penamaan berdasarkan persamaan, terdapat 5 jenis, yakni bola-bola, gemblong kancing, ketan uli, kuéh saroja, dan putri noong.

Misalnya 'bola-bola' adalah sejenis makanan yang bentuknya bundar seperti bola pingpong. Dengan demikian makanan ini diberi nama bola-bola;

(3) Penamaan berdasarkan bahan, terdapat 29 jenis, seperti bakasem kadongdong, cilok, cuing, dodol salak, kiripik bayem, kiripik nangka, kiripik sampeu, kulub 
hui, manisan tomat, peuyeum ketan, rujak kangkung, dan tumis rebung.

Kata 'peuyeum ketan' adalah nama makanan yang bahan dasarnya adalah beras ketan;

(4) Penamaan berdasarkan tempat asalnya, terdapat 2 jenis, yakni tahu lamping dan wajit Subang.

Kata 'wajit Subang' adalah nama makanan jenis wajit yang berasal dari daerah Subang Kuningan;

(5) Penamaan berdasarkan sifat yang menonjol, terdapat 6 jenis, yakni bolu ungu, bubur lemu, gemblong ungu, opak bakar, papais monyong dan raragudig. Kata 'papais monyong' adalah sejenis makanan yang bentuknya monyong seperti aseupan atau kerucut;

(6) Penamaan berdasarkan sebagian anggapan, terdapat 3 jenis, yakni bubur kemplang, buras, dan jawadah.

Kata 'bubur kemplang' adalah sejenis makanan yang cara pembuatannya dengan cara dipukul sampai bubuk. Kemplang didina mempunyai arti dipukul; dan

(7) Penamaan manasuka, terdapat 27 jenis, seperti ades, ampyang, bongko, béca, cimplo, emping, gendar, golono, jalabria, kasreng, leupeut, rubi-rubi, rarawuan dan wiwingka.

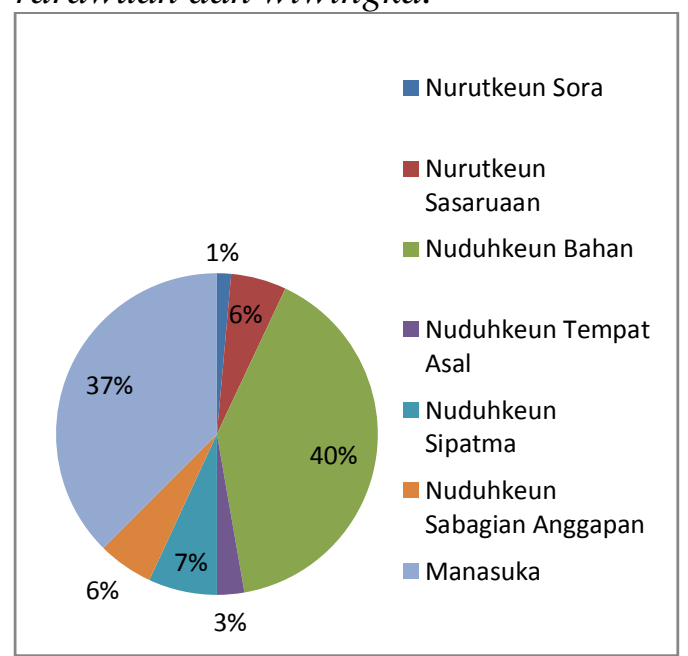

Diagram 2

Proses Penamaan Leksikon Makanan Tradisional Sunda di Kabupaten Kuningan

\section{Makna Leksikon Makanan Tradisional Sunda di Kabupaten Kuningan}

Makna leksikon makanan traditional Sunda yang biasa disebut kosakata dapat diartikan (a) Kekayaan kata yang dimiliki oleh suatu bahasa; (b) Semua kata yang terdapat dalam suatu bahasa; (c) Idiolek; kata-kata yang dikuasai oleh seseorang atau dialek; (d) Istilah; kata-kata yang dipakai dalam suatu bidang ilmu pengetahuan; (e) Glosarium; kamus sederhana, kamus dalam bentuk ringkas, daftar kata-kata di bidang tertentu dengan penjelasannya; (f) Komponen bahasa yang memuat semua informasi tentang makna dan pemakaiannya; (g) Kamus; daftar sejumlah kata atau frasa dari suatu bahasa yang disusun secara alfabetis disertai batasan dan keterangan lainnya (Adiwimarta, 1978:1; Kridalaksana, 1982:98; KBBI, 1988:510); dan (h) Enslikopedi; karya universal yang menghimpun uraian tentang berbagai cabang ilmu atau bidang ilmu tertentu dalam artikel-artikel terpisah dan tersusun menurut abjad.

Berdasarkan makna leksikonnya, semua leksikon makanan tradisional Sunda di Kabupaten Kuningan merupakan kata benda. Benda yang dimaksud adalah makanan tradisionalnya.

\section{Bahan Dasar Makanan Tradisional Sunda di Kabupaten Kuningan}

Leksikon makanan tradisional Sunda di Kabupatén Kuningan diklasifikasi berdasarkan beberapa kelompok. Ada sepuluh kelompok leksikon makanan tradisional Sunda di Kabupatén Kuningan, yakni beras, tepung beras, beras ketan, tepung ketan, singkong, tepung kanji, terigu, kacang, ubi, jagung, dan bahan lainnya.

(1) Makanan tradisional yang berbahan dasar beras terdapat $5(6,8 \%)$ jenis, yakni bongko, buras, gendar, hucap, dan kasréng;

(2) Makanan tradisional yang berbahan dasar tepung beras terdapat $7(9,6 \%)$ 
jenis, yakni apem, awug, bubur lemu, cimplo, cuhcur, kelepon, dan kuéh seroja;

(3) Makanan tradisional yang berbahan dasar beras ketan terdapat $10(13,7 \%)$ jenis, yakni bubur kemplang, dodol peuyeum, ketan uli, koécang, leupeut, peuyeum ketan, rangginang, raragudig, dan wajit subang;

(4) Makanan tradisional yang berbahan dasar tepung ketan terdapat $12(16,4 \%)$ jenis, yakni ades, awug, cikak, dodol salak, dodol peuyeum, dodol boléd, doko-doko, jawadah, jalabria, opak bakar, papais monyong, sasagon, dan wiwingka;

(5) Makanan tradisionla yang berbahan dasar singkong terdapat $8(11 \%)$ jenis, yakni béca, gémét, gemblong, gemblong kancing, gemblong ungu, getuk, kulub sampeu, dan putri noong;

(6) Makanan tradisional yang berbahan dasar kanji terdapat $1(1,4 \%)$ jenis, yakni cilok;

(7) Makanan tradisional yang berbahan dasar terigu terdapat $3(4,1 \%)$ jenis, yakni moho, pia-pia, dan rarawuan;

(8) Makanan tradisional yang berbahan dasar kacang terdapat $6(8,2 \%)$ jenis, yakni ampyang, koécang, kuéh satu, rarawuan, tahu lamping, dan tahu susu;

(9) Makanan tradisional yang berbahan dasar ubi terdapat $6(8,2 \%)$ jenis, yakni bola-bola, bolu ungu, dodol boléd, gemblong ungu, keremes, dan rubirubi;

(10) Makanan tradisional yang berbahan dasar jagung terdapat $1(1,4 \%)$ jenis, yakni jagong marning;

(11) Makanan tradisional yang berbahan dasar lainnya terdapat 23 (32\%) jenis, diantaranya bakasem kadongdong, emping, golono, keripik bayem, kulub hui, dan tumis rebung.

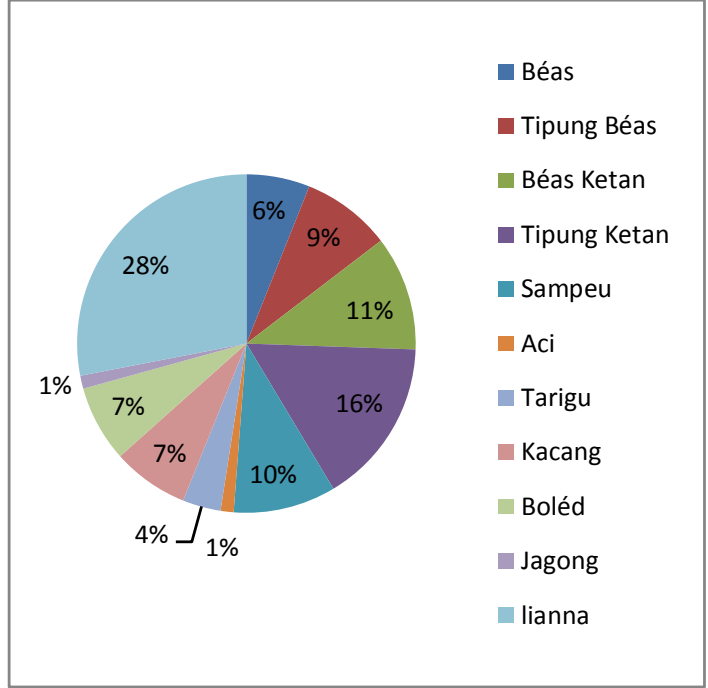

Diagram 3

Sumber Bahan pada Makanan Tradisional Sunda

\section{SIMPULAN}

Konsep makanan dan minuman pada masa kini, tidak hanya berkaitan dengan kata benda yang berfungsi mengisi dan mengenyangkan perut. Akan tetapi, pemahamannya bergeser kepada persoalan lingkungan, kesehatan, dan budaya. Menurut orang Sunda, makanan atau kadaharan adalah suatu benda yang dapat dimakan. Dalam budaya Sunda terdapat anggapan bahwa "seseorang belum dikatakan makan jika belum makan nasi dengan lauk pauknya". Berdasarkan strukturnya ditemukan empat bentuk leksikon makanan tradisional Sunda, yakni (1) bentuk tunggal, (2) bentuk turunan, (3) bentuk ulang, (4) bentuk majemuk, dan bentuk singkatan. Dari hasil analisis data ditemukan bahwa makanan tradisional Sunda pada umumnya berupa kata majemuk $37(50,7 \%)$, sisanya berbentuk kata dasar $22(30,1 \%)$, berbentuk kata ulang $8(10,9 \%)$, berbentu kata singkatan $5(6,8)$ dan berbentuk kata turunan $1 \quad(1,4 \%)$. penamaan, terdapat $1(1,4 \%)$ nama makanan yang berdasarkan peniruan bunyi, $4(5,5 \%)$ berdasarkan persamaan, 29 $(39,7 \%)$ berdasarkan bahan, $2(2,7 \%)$ berdasarkan tempat asalnya, $5 \quad(6,8 \%)$ berdasarkan penyebutan sifat khas, 4 
$(5,5 \%)$ berdasarkan sebagian anggapan, dan $27(37 \%)$ manasuka. Makna leksikon makanan traditional Sunda merujuk pada bentuk kata benda. Nama makanan tradisional Sunda di Kabupatén Kuningan berdasarkan bahannya adalah yang berbahan dasar beras ada $5(6,8 \%)$, tepung beras ada $7(9,6 \%)$, beras ketan ada 10 $(13,7 \%)$, tepung ketan ada $12(16,4 \%)$, singkong ada $8(11 \%)$, aci ada $1(1,4 \%)$, terigu ada $3(4,1 \%)$, kacang ada $6(8,2 \%)$, ubi ada $6(8,2 \%)$, jagung ada $1(1,4 \%)$, dan bahan lainnya ada $23(32 \%)$.

\section{PUSTAKA RUJUKAN}

Adimihardja, Kusnaka. (2005). Makanan dalam Khazanah Budaya. Bandung: Kerjasama UPT INRIK UNPAD \& DISBUDPAR JAWA BARAT.
Adiwimarta, Sri Sukesi. (1978). Tata Istilah Bahasa Indonesia. Jakarta: Pusat Bahasa.

Kridalaksana, Harimurti. (1982). Kamus Linguistik. Jakarta: Gramedia.

Sudaryat, Yayat dkk. (2007). Tatabasa Sunda Kiwari. Bandung: Yrama Widya.

Sudaryat, Yayat. (2009). Makna dalam Wacana. Bandung: Yrama Widya.

\section{UCAPAN TERIMA KASIH}

Penulis mengucapkan terima kasih kepada berbagai pihak yang telah membantu dalam penelitian dan penulisan artikel ini, baik kepada masyarakat Kuningan, para dosen Pendidikan Bahasa dan Budaya Sunda, teman sejawat mahasiswa SPs Sunda UPI. 